\title{
The History of the Great Duchy of Lithuania: Belarus' Medieval Origins
}

\author{
BY \\ RYHOR ASTAPENIA* \\ Kraucevič, Aliaksandr. \\ Historyja Vialikaha Kniastva Litoŭskaha. Ad pačatku haspadarstva da kara- \\ lieǔstva Litvy i Rusi (1248-1341) (The History of the Great Duchy of Lithuania. \\ From the Beginning of Husbandry till the Kingdom of Lithuania and Ruthenia \\ (1248-1341)), Haradzienskaja biblijateka: \\ Harodnia-Uroclaŭ, 2013. 184 pp. \\ 64,900 BYR \\ ISBN: 9788378931324.
}

'The History of the Great Duchy of Lithuania' takes Belarusians back to their own medieval origins, providing an additional contribution to the development of national self-identification. If the current authorities have a stake in the nation's Soviet heritage and oppose local historiography, books like 'The History of the $G D L$ ' nurture in Belarusians feelings of historical dignity, making them feel connected with their ancestors and their achievements.

The book argues that the Slavic segment of society dominated in the Grand Duchy of Lithuania, although it also shows that the Balts and Slavs coexisted peacefully in one state. Aliaksandr Kraŭcevič aptly describes their geopolitical choices and the recipe for success for the Grand Duchy of Lithuania.

Belarusian historian Aliaksandr Kraŭcevič considers the publication of a book series dedicated to the history of the GDL his life's work. The first book, which covers the first century of one of the formidable states in the Middle Ages, came out in print in the summer of 2013.

Aliaksandr Kraŭcevič, a Doctor of Science, remains one of the world's most famous Belarusian historians. He studied at the Belarusian State University and the Academy of Sciences of the USSR, worked at the Academy of Sciences

\footnotetext{
* Ryhor Astapenia is editor-in-chief of Belarusian internet-magazine Idea and a $\mathrm{PhD}$ candidate at the University of Warsaw.
} 
of Belarus and was the first Vice Rector of Hrodna State University. Today, Kraŭcevič is known not only as an academic historian, but also as one of the creators of the historical film series called 'History Under the Pogon Flag' on Belsat TV.

The author divides the first section of the book into two distinctive parts. The first depicts the state's formation: the beginning of husbandry, its first challenges from its neighbours, and the strengthening of the GDL. The second part is dedicated to the ruling of Grand Duke Gedimin. Kraŭcevič describes Gedimin's times, his numerous successes and rare failures. At the end of the book the author enlists sources, gives a rich bibliography, chronology of GDL history and an index.

He places the GDL dukes at the centre of his narrative writing mostly about wars and diplomacy, not culture. According to the author, the new state rose up to serve as a security guarantor against the Golden Horde and the Teutonic Order. The very beginnings of the GDL lies in the union concluded by regionally the largest Slavonic (Belarusian) city of Navahrudak and the powerful Baltic kunnigus Mindowg. The East-Slavonic element dominated the newly created duchy, which is reflected in the Belarusian language's status in the GDL.

It is notable that the mere study of the history of the GDL divides people who now inhabit the lands of the former state. ${ }^{1}$ Still many scholars, both in Belarus and Lithuania consider the GDL either as exclusively a Belarusian or Lithuanian state. Kraŭcevič refutes both camps, claiming that the peaceful co-existence of the Baltic and Slavonic tribes and that, 'the very genesis of the GDL can be considered a manifestation or an episode of Baltic-Slavonic interaction'.

The appearance of the first and the last king remains one of the most significant events in the history of the GDL. Approximately in 1253, Mindowg was crowned, and then there began a period, which, in the author's opinion, 'became the first political manifestation of the GDL's orientation toward Western European civilization'. Later Mindowg returned to heathendom. But religious tolerance remained a key value in a state that was shared by Lithuanians and Ruthenians, and a place where pagans, Catholics and Orthodox peacefully coexisted.

The lion's share of the book is dedicated to Gedimin. There appears to be two reasons for the author's decision to focus so much on Gedimin. First, there are few references to the start of the GDL in the existing historical sources. Secondly, it was Gedimin's foreign policy principles of 'defend in the West, attack in the East' that helped increase the size of the state's territory threefold in a span of 25 years.

\footnotetext{
${ }^{1}$ V. Rakutis, rector of the Lithuanian Military Academy, stated in September 2013 that Belarus held an informational war against Lithuania through the falsification of the GDL's history. See more at <http://www.lithuaniatribune.com/52087/belarusians-rewriting-history-do-you-think-youre-the-lithuanians-201352087/> [accessed 23 April].
} 
The Grand Duke was lionised in history as a strong warrior and perfect diplomat. He was successful at war, married off his children, found allies, signed peace treaties and was ready to change his religion if it benefitted the state. Gedimin came to power in 1316 when the territory of the state was around 90,000 square kilometres. 25 years later he left the state with a territory of nearly 320,000 square kilometres. The current Republic of Belarus constitutes a considerable part of this territory today.

In the book, the author balances between popular and scholarly literature. Aliaksandr Kraŭcevič provides an expansive bibliography, often referring to other academics' work. Extracts from chronicles significantly improve the book. Still, the author is not above including a rather artistic reconstruction of Mindowg's baptism in the book.

The author considers the history of the GDL in the context of its neighbouring states. The book contains much information not only about the GDL, but also about neighbouring Žemaitija and Inflanty, the Tectonic Order State and Mazowsze, the Kingdom of Poland, the Principality of Galicia-Volhynia, the Kyivian Lands, the Principality of Moscow, Pskov and the Novgorod Republic. He shows the environment of the present day Belarusians' and Lithuanians' motherland, as well as their place in Europe.

Kraŭcevič's book plays a great role not only in the development of Belarusian historiography, but also in civil and political discourse. The history of the Great Duchy is still perceived in two ways in Belarus. On the one side, both the state and society recognise the GDL as having a historical heritage that is distinctly Belarusian. On the other side, civil society and the state institutions are not involved in preserving this heritage at a sufficient level. Most streets in Belarus have received their names not in honour of the Duchy's heroes, but in honour of Soviet-era personalities, some of whom brought much harm to Belarus. Moreover, the authorities never call the GDL dukes Belarusian politicians, nor do they mention the role of Magdeburg rights for Belarusian cities in the public psyche.

Although the author claims he would like to make the book easier to read, there are still several points to be improved. The book does not contain a sufficient number of maps and pictures which would have made the historical text more intelligible. For example, when the author recalls Vicien's recognition of 'Pahonia' as a state symbol, it would have been reasonable to show what the 'Pahonia' looked like at this time, or due to the lack of a preserved 'Pahonia' during Vicien's time, what the symbol looked like in an era close to this period. Kraŭcevič establishes his sources quite well throughout the book. His study seems feasible, but the text itself could have been less overloaded with facts. 
Despite the desire of state propagandists to have it otherwise, the history of the GDL connects Belarus with a greater heritage. The actions of the current authorities on the limitation of history to the Soviet period are guided by an understanding that perceiving one's history influences the development of a modern society's civil life. Therefore, Kraŭcevič's book makes a great contribution by sharing the glorious victories of the past, the unique religious tolerance that then existed and the examples of the great statesmen of history. 'The History of the Grand Duchy of Lithuania' has not only cultural and historical value, but also supports Belarusians' strengthen their own national identity. 